\section{Estudo \\ CoDebate}

em Testão

Planejamento
Revista Estudo \& Debate, Lajeado, v. 24, n. 3, 2017. ISSN 1983-036X

DOI: http://dx.doi.org/10.22410/issn.1983-036X.v24i3a2017.1419

\title{
RELEVÂNCIA DO PROGRAMA BOLSA FAMÍLIA PERANTE AS PRINCIPAIS RECEITAS TRIBUTÁRIAS E O PIB DOS MUNICÍPIOS DA MICRORREGIÁO DA AMUREL
}

\author{
Rodney Wernke ${ }^{1}$, Andrey Pereira dos Santos ${ }^{2}$, Ivone Junges ${ }^{3}$
}

\begin{abstract}
Resumo: A pesquisa abordou o nível de relevância dos recursos destinados pelo Programa Bolsa Família (PBF) perante o PIB e às fontes de receitas municipais mais importantes, a partir de dados da contabilidade pública das prefeituras dos municípios da microrregiáo da Amurel (sul de Santa Catarina). Objetivou mensurar a proporçáo (em termos percentuais) dos valores destinados pelo PBF em relação às receitas tributárias próprias e ao PIB da região. A metodologia de pesquisa descritiva, de corte seccional e com abordagem quantitativa. Foi constatado, que os valores destinados pelo Programa Bolsa Família aos beneficiários dos municípios da microrregiáo tiveram percentual de participaçáo médio perante o PIB da Amurel (de 0,151\%), o que é inferior à participaçáo deste no PIB brasileiro (de 0,414\%), mas é superior à participação do mesmo no PIB de Santa Catarina (de 0,104\%) no quadriênio abrangido. Apurou-se que há níveis distintos de importância do programa assistencial entre os municípios pertencentes à Amurel e que em diversas cidades o percentual do montante do PBF superou o total arrecadado com IPTU no quadriênio (com máxima de 1.233,20\% e mínima de $115,50 \%$ entre os dez que superaram a proporção do Bolsa Família sobre este tributo). A contribuição do estudo reside em evidenciar a relevância econômica dos recursos alocados pelo Bolsa Família na microrregião da Amurel em termos de arrecadação tributária municipal.
\end{abstract}

Palavras-chave: Programa Bolsa Família. Microrregião da Amurel. Levantamento.

\section{RELEVANCE OF THE BOLSA FAMÍLIA PROGRAM TO THE MAIN TAX REVENUES AND GDP OF THE MUNICIPALITIES OF THE AMUREL MICROREGION}

\begin{abstract}
The research focused on the level of relevance of the resources allocated by the Bolsa Família Program $(\mathrm{PBF})$ to the GDP and to the most important municipal revenue sources, based on public accounting data from municipalities in the municipalities of the Amurel microregion (south of Santa Catarina). It aimed to measure the proportion (in percentage terms) of the values destined by the PBF in relation to the own tax revenues and the GDP of the region. The descriptive research methodology, with a cross-sectional and quantitative approach.
\end{abstract}

1 Contador, doutor, professor e pesquisador da Unisul (Universidade do Sul de Santa Catarina).

2 Administrador, atua em empresa da regiâo sul de Santa Catarina.

3 Economista, doutora, professora e pesquisadora na Unisul (Universidade do Sul de Santa Catarina). 
It was verified that the amounts destined by the Bolsa Família Program to the beneficiaries of the municipalities of the microregion had an average participation percentage in relation to Amurel's GDP (of $0.151 \%$ ), which is lower than its share in the Brazilian GDP $(0.414 \%)$, but Is higher than its participation in the GDP of Santa Catarina $(0.104 \%)$ in the four-year period covered. It was found that there are distinct levels of importance of the assistance program among the municipalities belonging to Amurel and that in several cities the percentage of the amount of the PBF exceeded the total collected with IPTU in the quadrennium (maximum of 1,233.20\% and minimum of $115,50 \%$ among the ten that surpassed the proportion of Bolsa Familia on this tribute). The contribution of the study is to highlight the economic relevance of the resources allocated by the Bolsa Família in Amurel microregion in terms of municipal tax collection.

Keywords: Bolsa Família Program; Amurel Microregion; Survey.

\section{Introduçáo}

Uma das mais respeitadas publicações sobre relações internacionais, a revista americana Foreign Affair publicou na sua primeira edição de 2016 uma matéria enaltecendo o programa assistencial brasileiro conhecido como Bolsa Família. No artigo "A Importante Descoberta Brasileira Antipobreza - O Sucesso Surpreendente do Bolsa Família”, o periódico norte-americano definiu-o como um esforço de combate à pobreza revolucionário em seu tamanho, ambiçáo e desenho, além de afirmar que a iniciativa é um exemplo a ser seguido por outros países. "Há não muito tempo, a ideia de que o Brasil pudesse ter algo a ensinar ao mundo sobre redução da desigualdade poderia soar como uma piada", registrou o editor da revista Jonathan Tepperman. A reportagem enalteceu o impacto da transferência de renda em momentos de crise e defendeu que "o Bolsa Família também provou ser um importante colchão de garantia de direitos quando o crescimento do país desacelerou nos últimos anos. A economia do país pode estar sofrendo hoje, mas graças à proteção garantida pelo Bolsa Família, a população não sofre da mesma forma que sofreu em crises anteriores" (Tepperman, 2016). Também salientou que a melhor prova do sucesso do programa é o fato de que, desde sua criação, delegaçóes de 63 naçōes já vieram ao país para conhecê-lo, bem como o fato de ter recebido elogios de organismos como Fundo Monetário Internacional (FMI), Organização das Nações Unidas (ONU), Banco Mundial (BIRD), entre outros.

Da mesma forma, pesquisas acadêmicas sobre os efeitos práticos do PBF têm sido divulgadas com ênfase nos benefícios econômicos e/ou sociais para o país como um todo (Jannuzzi \& Pinto, 2013), para determinadas classes sociais (Souza \& Osorio, 2013) ou para estados/regiōes do país menos desenvolvidos economicamente (Silveira Neto \& Azzoni, 2013). Entretanto, não foram encontrados estudos que versassem sobre o Bolsa Família com enfoque atrelado à contabilidade pública dos municípios ou microrregióes.

Nesse sentido, os aspectos positivos deste programa talvez possam ser identificados também com base em dados contábeis nos municípios sul-catarinenses, em que pese haver cidades bastante heterogêneas em termos de densidade populacional, relevo, etnias predominantes, atividades econômicas, extensão territorial, localização geográfica etc.

Em virtude do exposto, se pretende encontrar resposta para a seguinte questão de pesquisa: qual a proporçáo percentual dos recursos destinados pelo Programa Bolsa Família aos beneficiários residentes nos municípios integrantes da microrregião da Amurel (Associaçáo dos Municípios de Laguna, no sul de Santa Catarina) perante as principais receitas tributárias municipais e o PIB dessas cidades? Referida questão está alicerçada em 
duas hipóteses: ( $i$ ) como fonte de renda para dinamizar a economia de cidades catarinenses, o Bolsa Família pode superar tradicionais fontes de receitas tributárias municipais (como IPTU, IPVA-Cota Parte e ICMS-Cota Parte) e (ii) o volume de recursos deste programa social está distribuído de forma heterogênea entre os municípios e, por isso, tende a ter níveis de relevância díspares nessas áreas geográficas. Com base nessas cogitações foi estabelecido como objetivo de estudo comparar os valores destinados pelo $\mathrm{PBF}$ em relação às principais receitas tributárias e ao PIB dos municípios que integram a microrregiáo citada.

Estudo com esse enfoque se justifica porque a grande maioria dos artigos que versam sobre o Programa Bolsa Família abordam o assunto sob o prisma dos aspectos sociais e econômicos. Com isso, no âmbito das publicaçôes sobre contabilidade não foram encontradas publicaçóes que discorressem sobre o tema, o que constitui uma lacuna de pesquisa que merece ser melhor explorada do ponto vista contábil. Adicionalmente, estudos sobre o assunto tendem a contribuir para um conhecimento maior sobre a influência que esse tipo de programa social causa, o que pode auxiliar na formação de opiniōes mais bem fundamentadas e abrir a possibilidade de novas pesquisas no âmbito da contabilidade pública.

\section{Revisão da Literatura}

O escorreito entendimento do estudo requer a compreensão dos termos relacionados, cujos principais aspectos são comentados a seguir.

\subsection{Receitas Tributárias Municipais}

A partir da promulgação da Constituição Federal do Brasil de 1988 foram atribuídas aos municípios mais competências tributárias próprias, além de terem sido ampliadas as participaçôes destes entes federativos no montante arrecadado de impostos das esferas federal e estadual. Ou seja, a receita municipal é formada pela arrecadação tributária própria e transferências intergovernamentais (Reis, Costa \& Silveira, 2013).

Quanto às modalidades de receitas tributárias próprias dos municípios, neste rol podem ser inseridas as formas de arrecadação vinculadas ao Imposto sobre a Propriedade Predial e Territorial Urbana (IPTU), ao Imposto sobre Transmissão de Bens Imóveis (ITBI), ao Imposto Sobre Serviço de Qualquer Natureza (ISS), às contribuiçóes de melhorias e às taxas que possam vir a ser cobradas pela administração pública municipal (Kohama 2012).

As transferências governamentais abrangem as cotas-partes do ICMS e do IPVA, ao Fundo de Participação dos municípios (FPM), ao Fundo do IPI-Exportação (FPEEX), ao Imposto Territorial Rural (ITR) e ao Fundo de Manutençấo e Desenvolvimento da Educação Básica (FUNDEB), entre outras possibilidades (Andrade, 2010). Destes recursos transferidos, as fontes de valores mais significativas tendem a ser o Fundo de Participação Municipal (FPM), que é uma transferência da Uniáo às prefeituras e a cota-parte do Imposto sobre Circulação de Mercadorias e Serviços (ICMS), que é proveniente do governo estadual (Gouvêa, Varela \& Farina, 2010).

Contudo, neste estudo foram priorizadas somente as receitas tributárias próprias dos municípios, o IPTU e as cotas-parte de IPVA e ICMS. Acerca disso, Andrade (2002) 
cita que as receitas tributárias municipais são derivadas de tributos como impostos, taxas e contribuiçóes de melhoria. Referido autor esclarece que a rubrica "Impostos" (conta 1110.00.00) envolve o valor arrecadado com IPTU, ITBI, Imposto sobre a Renda e Proventos de Qualquer Natureza e Impostos sobre a Produção e a Circulação e que sob a denominação "Taxas" (conta 1120.00.00) estão aqueles tributos cujo fato gerador é o exercício regular do poder de polícia, ou a utilização, efetiva ou potencial, de serviços públicos específicos e divisíveis. Além disso, no caso das "Contribuiçôes de Melhoria" (conta 1130.00.00), estas se referem ao valor total da arrecadação dos proprietários de imóveis beneficiados por obras públicas.

No que concerne ao IPTU, sua constitucionalidade foi prevista no artigo $156 \mathrm{da}$ Constituição Federal de 1988, mas já havia previsão a respeito no Código Tributário Nacional instituído pela Lei no. 5172/66, visto que tal imposto era mencionado nos seus artigos 32, 33 e 34. A arrecadação desse tributo é de responsabilidade dos municípios e seu fato gerador ocorre pela propriedade, o domínio útil ou a posse de bem imóvel por natureza ou por acessão física, como definido na lei civil, localizado na zona urbana do município. O contribuinte pode ser o proprietário do imóvel, o titular do seu domínio útil, ou o seu possuidor a qualquer título, sendo que a base de cálculo é dada pelo valor venal (valor de venda) dos imóveis e sua alíquota varia de um município para outro, sendo admissível sua progressividade após a edição da Emenda Constitucional 29/2000. Quanto à sua participação na arrecadação tributária brasileira, Avila e Conceição (2015) asseveram que este representa cerca de1,4\% da arrecadação tributária total do Brasil e costuma ser uma importante fonte de receita para as prefeituras brasileiras.

Quanto ao IPVA, no estado de Santa Catarina é a Lei n $7.543 / 88$ que regulamenta esse tributo incidente sobre o valor de veículo automotor sujeito a licenciamento pelos órgãos competentes. Destarte, no artigo 11 dessa lei foi estabelecido que do produto da arrecadação deste imposto $50 \%$ (cinquenta por cento) serão destinados ao município em que estiver registrado, matriculado ou licenciado o veículo. Quanto à sua relevância no bolo tributário nacional, Avila e Conceição (2015) aduzem que este responde por 1,7\% da arrecadação total brasileira.

Acerca do ICMS, a legislação prevê que 25\% do total arrecadado com esse imposto pelo Estado seja repassado aos municípios a partir de critérios que levam em conta, entre outros, principalmente a movimentação econômica das cidades em termos de valor adicionado (Reis, Costa \& Silveira, 2013). No que se refere ao fator "valor adicionado", este pode ser considerado o mais importante por duas razóes: $(i)$ por determinação constitucional o valor adicionado deve responder por dois terços do índice a ser utilizado para apurar o percentual de repasse do ICMS aos municípios e (ii) é um componente que pode ser administrado pela organização, ainda que parcialmente (Matias \& Campello, 2000).

No contexto catarinense a divisão entre o agente arrecadador (governo estadual) e os municípios é regida pela Portaria no. 233/2012 da Secretaria Estadual da Fazenda, que se coadunou ao disposto no art. 158, inciso IV da Constituição Federal e Lei no 7.721 , de 06 de setembro de 1989. Por esse motivo, como o total dessas transferências está atrelado à geração de riquezas no território municipal, as cidades menos evoluídas economicamente 
não são tão beneficiadas com esses repasses como aquelas com atividade econômica mais intensa.

\subsection{Programa Bolsa Família}

O Programa Bolsa Família (PBF), conforme consta do site do Ministério do Desenvolvimento Social e Combate à Fome (MDS, 2016), foi instituído em outubro de 2003, tendo sido previsto pela Lei Federal no 10.836/2004, com regulamentação dada por intermédio do Decreto no 5.209/2004 e outras normas posteriores. Desde 2011 este programa social integra o Plano Brasil Sem Miséria, que reuniu diversas iniciativas que visam permitir que as famílias deixem a extrema pobreza por meio da facilitação do acesso a direitos básicos e a oportunidades de trabalho, bem como pelo fomento ao empreendedorismo. Com o intuito de auxiliar no combate à pobreza e à desigualdade no Brasil, o programa possui três eixos:

1) Servir como complemento da renda visto que, todos os meses, as famílias atendidas pelo Programa recebem um benefício em dinheiro, que é transferido por via bancária diretamente pelo governo federal às beneficiárias (mães das famílias carentes). Com isso, visa garantir o alívio mais imediato da pobreza;

2) Permitir acesso a direitos, pois as famílias devem cumprir alguns compromissos (condicionalidades), que têm como objetivo reforçar o acesso à educação, à saúde e à assistência social. Essas exigências oferecem condições para as futuras gerações quebrarem o ciclo da pobreza, graças a melhores oportunidades de inclusão social;

3) Articulação com outras ações, de vez que o Bolsa Família tem capacidade de integrar e articular várias políticas sociais a fim de estimular o desenvolvimento das famílias, contribuindo para elas superarem a situação de vulnerabilidade e de pobreza.

Campello (2015) esclarece quanto aos valores dos benefícios concedidos e à população abrangida. Salienta que o valor máximo pago pelo PBF era de R $\$ 77,00$ por beneficiário (cada membro da família carente), sendo que esse limite se aplicava somente nos casos em que o grupo familiar não tinha nenhuma fonte de renda e o valor médio pago às famílias cadastradas era de $\mathrm{R} \$ 170,00$. Destaca também que esses $\mathrm{R} \$ 77,00$ são pagos para aqueles que não têm nenhuma renda (zero), multiplicado pelo número de pessoas da família. Porém, é muito difícil encontrar renda zero entre todos os membros da família, porque, em geral, sempre há alguma pessoa produzindo alguma coisa. Os números totais revelam que, do total de 14 milhóes de famílias beneficiadas, apenas 25 famílias recebem mais do que mil reais. Mais de $80 \%$ ganham menos de 500 reais.

\subsection{Aspectos Positivos Associados ao PBF}

Diversos estudos comprovaram os aspectos benéficos relacionados com o Programa Bolsa Família. Nesse sentido, as condicionalidades (exigências que os beneficiários têm que cumprir) do PBF acarretam melhorias em indicadores relacionados à educação e à saúde de determinado contingente da população brasileira. Acerca disso, há evidências de que referida iniciativa governamental: 
a) Aumenta a frequência escolar e a proporção de crianças adequadamente vacinadas nas idades corretas (Januzzi \& Pinto, 2013).

b) Reduz os índices de repetência de alunos de primeiro grau (Oliveira \& Soares, 2013; Cireno, Silva \& Proença, 2013).

c) Diminui a inatividade dos brasileiros "nem-nem", ou seja, daqueles que "nem estudam e nem trabalham” (Silveira, Campolina \& Horn, 2013).

d) Minimiza a mortalidade em crianças menores de cinco anos (Rasella et al., 2013).

e) Reduz a prevalência de baixo peso ao nascer (Santos et al., 2013).

Por outro ângulo, Soares, Ribas e Osorio (2010) confrontaram os impactos do Bolsa Família com o de outros programas de transferências condicionadas de renda adotados no México, Colômbia, Equador e Chile. Constataram que, assim como os programas dos países citados, o Bolsa Família ajuda a reduzir a desigualdade e a extrema pobreza e tem impactos positivos sobre indicadores educacionais, sem apresentar resultados negativos sobre a participação na força de trabalho.

Quanto às críticas de que tal programa estimularia a indolência ou o aumento dos índices de natalidade, alguns estudos mostram avaliaçóes que não indicam que o PBF tenha qualquer efeito sobre preguiça (Oliveira \& Soares, 2013b), nem que sirva como estímulo à informalidade ou à maior fecundidade (Barbosa \& Corseuil, 2013), visto que estas têm caído em todas as classes de renda, mas principalmente entre a população mais pobre e no Nordeste (Alves \& Cavenaghi, 2013). Nesse sentido, famílias sem crianças já são mais comuns do que famílias com quatro ou mais crianças entre os brasileiros mais pobres (Souza \& Osório, 2013).

Por seu turno, Craveiro e Ximenes (2013) priorizaram os impactos do Bolsa Família no contexto educacional e concluíram que a condicionalidade de educação do PBF exige frequência escolar de $85 \%$ para crianças e adolescentes de 6 a 15 anos e de $75 \%$ para jovens de 16 e 17 anos. Para chegar a esses resultados, foi necessário coletar e processar dados a respeito e fazer o acompanhamento bimestral, o que é efetuado por intermédio de açóes articuladas entre o Ministério da Educação (MEC) e o Ministério do Desenvolvimento Social e Combate à Fome (MDS). Assim, se houver o descumprimento da frequência mínima, as escolas precisam registrar os motivos. Para as famílias que apresentam casos reiterados de descumprimento, a rede de assistência social é acionada para apoiar no enfrentamento de situaçôes de vulnerabilidade e risco social. Além disso, no que tange ao total de estudantes com até 15 anos concluintes do ensino fundamental regular, mesmo que o resultado nacional dos estudantes de famílias beneficiadas pelo PBF $(75,6 \%)$ seja um pouco inferior ao dos demais alunos da rede pública $(79,4 \%)$, seus resultados são melhores nas regióes mais pobres e com maior cobertura do programa. Nesse ponto, o destaque maior é a região Nordeste, onde $71,3 \%$ dos estudantes do PBF conseguem terminar o ensino fundamental até os 15 anos, contra 64\% dos demais na rede pública. 


\subsection{Pesquisas com Foco Assemelhado}

No final de novembro de 2016 foram realizadas pesquisas com o fito de encontrar estudos com abordagem assemelhada à escolhida para este estudo. Para tanto, foram efetuadas buscas online utilizando termos/expressóes relacionados ao "Bolsa Família" e/ou "Programa Bolsa Família" nos sítios das revistas científicas brasileiras voltadas à contabilidade e classificadas pelo ranking Qualis/Capes entre os estratos A1 e B2, conforme divulgado no segundo semestre de 2015. Porém, não foram encontradas publicaçóes nessas revistas acerca do assunto proposto. Em seguida, foi realizada busca no "Portal de Periódicos Capes" com a mesma intenção, quando foram encontradas nesse portal mais de uma centena de publicaçóes que discorriam sobre o PBF, mas que focavam aspectos diferentes da abordagem contábil proposta neste estudo. Os resultados dos procedimentos citados demonstram existir uma lacuna de pesquisa na seara da contabilidade pública que merece ser melhor explorada.

\section{Metodologia da Pesquisa}

Tendo em lume o propósito de investigar a relevância do PBF nas receitas municipais próprias e no PIB de todos os municípios da microrregião da Amurel, entre 2010 e 2013, foi realizada uma pesquisa descritiva (quanto ao objetivo), de corte seccional (quanto ao período de tempo abrangido) e quantitativa (quanto à forma de tratamento dos dados).

Nesse rumo, uma pesquisa descritiva visa descrever como os fenômenos de atuação prática se desenvolvem, proporcionando elementos que permitem conhecer o problema de pesquisa (Collins \& Hussey, 2005). Ainda, o estudo se caracteriza como de corte seccional (cross-sectional) de vez que investiga fenômeno que ocorre em um corte transversal no tempo, efetuando análises detalhadas para fundamentar observaçóes alcançadas uma única vez (Babbie, 1999). Quanto ao enfoque quantitativo, Richardson (1999) aduz que essa modalidade de pesquisa se refere àquelas que empregam a quantificação, tanto nas modalidades de coleta de informaçóes, quanto no tratamento dessas por meio de técnicas estatísticas, desde as mais simples, como percentual, média, desvio padrão, às mais complexas, como coeficientes de correlação, análises de regressão etc.

No que concerne à população abrangida, foram obtidos dados acerca de todos os municípios da microrregião da Amurel nesses quatro anos pesquisados. Contudo, um dos municípios foi criado em 2013 (Pescaria Brava) e, para não distorcer a comparabilidade dos demais, referida cidade foi desconsiderada nas análises ora relatadas.

Os dados foram coletados em fevereiro em novembro de 2015 em três fontes online: IBGE (informaçóes relacionadas ao PIB), Portal da Transparência da Controladoria Geral da União (quanto aos dados acerca dos valores do PBF repassados aos municípios abrangidos) e Relatório Finanças do Brasil - FINBRA, do site da Secretaria do Tesouro Nacional (para as informaçóes sobre as receitas municipais utilizadas). Os dados coligidos foram inicialmente avaliados quanto à existência de inconsistências ou de ausências específicas para algum município. Posteriormente foram tabulados em planilhas Excel, atualizados/inflacionados os valores monetários de 2010, 2011 e 2012 pelo IPCA para poder aquisitivo equivalente ao ano de 2013 e formatadas as tabelas utilizadas nas próximas seçóes. 


\section{Apresentaçáo e Discussão dos Resultados}

Nas fontes de pesquisa citadas anteriormente foram coletados os dados que fundamentaram a pesquisa, conforme descrito na sequência com a respectiva análise dos resultados.

A seguir a Figura 1 ilustra o mapa de Santa Catarina, posicionando a microrregiáo da Amurel - Associaçâo dos Municípios da Região de Laguna, no sul do estado.

Figura 1 - Mapa de Santa Catarina, posicionando a microrregiáo da Amurel

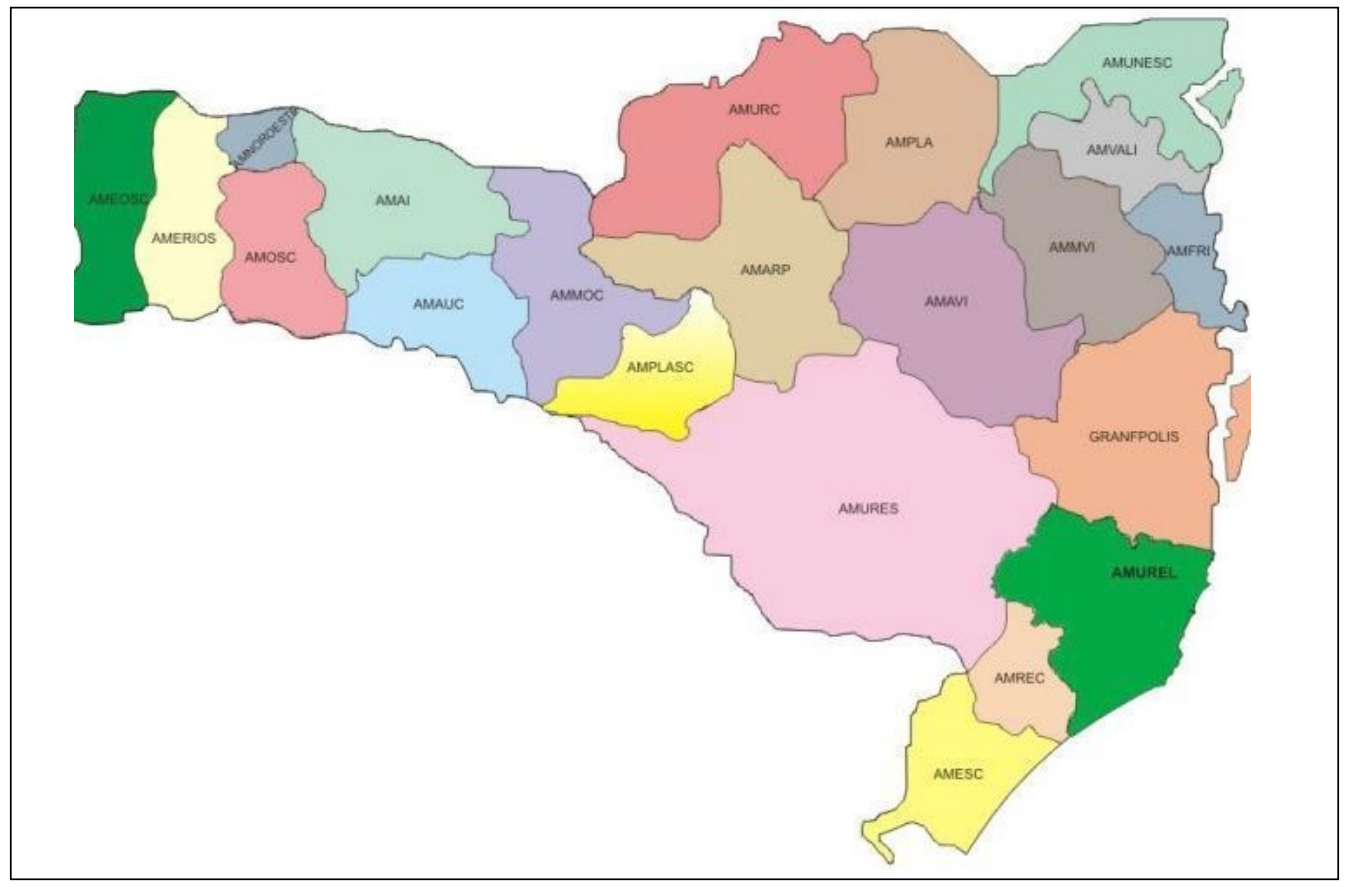

Fonte: http://www.amurel.org.br/cms/pagina/ver/codMapaItem/45287, 2017.

Quanto aos valores totais pertinentes ao PIB e aos benefícios do Bolsa Família, estes estão representados (em mil R \$) na Tabela 1 para a série histórica de 2010 a 2013, com os valores monetários de 2010, 2011 e 2012 atualizados para 2013 pelo índice anual do IPCA.

Tabela 1 - PIB versus Bolsa Família no Brasil, em S. Catarina e na Amurel (em mil R\$)

\begin{tabular}{l|r|r|r|r|r}
\hline Valores monetários de 2010, 2011 e 2012 inflacionados para 2013 pelo IPCA \\
\hline Itens & Ano 2010 & Ano 2011 & Ano 2012 & Ano 2013 & Média Quadr. \\
\hline PIB total do país (mil R\$) & 4.638 .975 .767 & 4.902 .658 .233 & 5.089 .942 .458 & 5.316 .453 .957 & 4.987 .007 .604 \\
\hline PIB total de SC (mil R\$) & 183.525 .323 & 195.098 .001 & 202.961 .424 & 214.217 .265 & 198.950 .503 \\
\hline PIB total da Amurel (mil R\$) & 7.010 .201 & 7.260 .760 & 7.731 .677 & 8.371 .269 & 7.593 .477 \\
\hline \% de SC no PIB do país & $3,956 \%$ & $3,979 \%$ & $3,987 \%$ & $4,029 \%$ & $3,988 \%$ \\
\hline$\%$ da Amurel no PIB do país & $0,151 \%$ & $0,148 \%$ & $0,152 \%$ & $0,157 \%$ & $0,152 \%$ \\
\hline
\end{tabular}




\begin{tabular}{|c|c|c|c|c|c|}
\hline \multicolumn{6}{|c|}{ Valores monetários de 2010, 2011 e 2012 inflacionados para 2013 pelo IPCA } \\
\hline Itens & Ano 2010 & Ano 2011 & Ano 2012 & Ano 2013 & Média Quadr. \\
\hline B.-Fam. total do país $(\mathrm{R} \$ \mathrm{mil})$ & 17.150 .340 & 19.373 .521 & 21.487 .950 & 24.890 .107 & 20.725 .480 \\
\hline B.-Fam. total de SC (R\$ mil) & 174.887 & 193.706 & 218.670 & 239.764 & 206.757 \\
\hline B.-Fam. total da Amurel (R\$ mil) & 10.534 & 11.422 & 11.688 & 12.097 & 11.435 \\
\hline \% de SC no BF do país & $1,020 \%$ & $1,000 \%$ & $1,018 \%$ & $0,963 \%$ & $1,000 \%$ \\
\hline \% da Amurel no BF do país & $0,061 \%$ & $0,059 \%$ & $0,054 \%$ & $0,049 \%$ & $0,056 \%$ \\
\hline \% B.-Fam. Total / PIB (Brasil) & $0,370 \%$ & $0,395 \%$ & $0,422 \%$ & $0,468 \%$ & $0,414 \%$ \\
\hline \% B.-Fam. SC / PIB (SC) & $0,095 \%$ & $0,099 \%$ & $0,108 \%$ & $0,112 \%$ & $0,104 \%$ \\
\hline $\begin{array}{l}\begin{array}{l}\% \text { B.-Fam. Amurel / PIB } \\
\text { (Amurel) }\end{array} \\
\end{array}$ & $0,150 \%$ & $0,157 \%$ & $0,151 \%$ & $0,145 \%$ & $0,151 \%$ \\
\hline
\end{tabular}

Fonte: elaborada pelos autores, com dados do IBGE e do Portal da Transparência (CGU).

A partir dos dados da Tabela 1 é possível identificar que a participação da microrregião da Amurel no PIB do país evoluiu de forma irregular ao longo dos quatro anos investigados e este comportamento foi diferente da performance do estado de Santa Catarina. Enquanto o PIB estadual aumentou a participação no PIB nacional em todos os períodos, o grupo de municípios da Amurel teve percentual menor em 2011 (0,151\%) em relação a 2010 (0,148\%), aumentou no ano de 2012 para $0,152 \%$ e finalizou a série com $0,157 \%$.

Quanto ao percentual do estado nos recursos destinados ao Bolsa Família em âmbito nacional, Santa Catarina participou com a média de $1,00 \%$ no quadriênio pesquisado. Por sua vez, na Amurel esse percentual correspondeu a $0,056 \%$ do total do programa. Contudo, nesta microrregiáo os percentuais a respeito ficaram menores a cada ano, passando de $0,061 \%$ em 2010 para $0,059 \%$ em 2011, caiu para $0,054 \%$ em 2012 e se reduziu para $0,049 \%$ em 2013.

A comparar os valores do PBF em proporção aos montantes do PIB do país, do estado e da microrregiāo constatou-se que a média nacional destes anos se situou em $0,414 \%$, a estadual ficou em $0,104 \%$ e $0,151 \%$. Ou seja, de cada R 100 do PIB da Amurel, os recursos do Bolsa Família alocados aos municípios representaram R \$ 0,151 (em média). Esse resultado superou o índice equivalente da Amurel (R\$ 0,104), mas ficou bem abaixo do nacional $(\mathrm{R} \$ 0,414)$. Portanto, o programa em tela tem relevância econômica maior para a microrregiáo do que tem para o estado barriga-verde e inferior à média do contexto brasileiro.

$\mathrm{Na}$ sequência passaram a ser abordados os municípios integrantes da Amurel de forma mais específica. Acerca disso, a Tabela 2 demonstra os valores totais do PBF em cada uma destas cidades e respectivos percentuais de participação no total desta regiáo. 
Tabela 2 - Bolsa Família por município (valores em mil R\$)

\begin{tabular}{|c|c|c|c|c|c|}
\hline \multicolumn{6}{|c|}{ Valores monetários de 2010, 2011 e 2012 inflacionados para 2013 pelo IPCA } \\
\hline Municípios & Ano 2010 & Ano 2011 & Ano 2012 & Ano 2013 & Média Quadr. \\
\hline Armazém & 259,8 & 297,1 & 307,9 & 263,1 & 282,0 \\
\hline Braço do Norte & 704,9 & 846,8 & 913,2 & 937,0 & 850,5 \\
\hline Capivari de Baixo & 769,5 & 813,7 & 794,6 & 768,4 & 786,6 \\
\hline Grão-Pará & 135,7 & 157,1 & 150,2 & 142,7 & 146,5 \\
\hline Gravatal & 365,5 & 422,2 & 469,5 & 450,3 & 426,9 \\
\hline Imaruí & 979,7 & $1.065,2$ & $1.240,9$ & $1.569,5$ & $1.213,8$ \\
\hline Imbituba & $1.540,6$ & $1.547,0$ & $1.829,0$ & $2.295,0$ & $1.802,9$ \\
\hline Jaguaruna & 681,7 & 724,2 & 747,0 & 722,0 & 718,7 \\
\hline Laguna & $2.668,1$ & $2.826,0$ & $2.510,3$ & $2.236,7$ & $2.560,3$ \\
\hline Pedras Grandes & 145,1 & 164,9 & 170,5 & 145,2 & 156,4 \\
\hline Rio Fortuna & 82,5 & 81,0 & 79,3 & 76,6 & 79,9 \\
\hline Sangão & 334,4 & 362,3 & 397,4 & 436,0 & 382,5 \\
\hline Sta. Rosa de Lima & 64,2 & 58,5 & 52,7 & 38,8 & 53,6 \\
\hline São Ludgero & 215,1 & 226,9 & 232,4 & 212,7 & 221,8 \\
\hline São Martinho & 113,1 & 121,5 & 106,8 & 101,3 & 110,7 \\
\hline Treze de Maio & 306,0 & 308,8 & 194,9 & 166,4 & 244,0 \\
\hline Tubarão & $1.167,4$ & $1.398,6$ & $1.491,2$ & $1.531,2$ & $1.397,1$ \\
\hline Total & $10.533,6$ & $11.421,6$ & $11.688,0$ & $12.096,7$ & $11.435,0$ \\
\hline \multicolumn{6}{|c|}{ Percentual de participação do município no total do Bolsa Família da Amurel } \\
\hline Municípios & Ano 2010 & Ano 2011 & Ano 2012 & Ano 2013 & Média Quadr. \\
\hline Armazém & $2,47 \%$ & $2,60 \%$ & $2,63 \%$ & $2,17 \%$ & $2,47 \%$ \\
\hline Braço do Norte & $6,69 \%$ & $7,41 \%$ & $7,81 \%$ & $7,75 \%$ & $7,44 \%$ \\
\hline Capivari de Baixo & $7,31 \%$ & $7,12 \%$ & $6,80 \%$ & $6,35 \%$ & $6,88 \%$ \\
\hline Grão-Pará & $1,29 \%$ & $1,38 \%$ & $1,29 \%$ & $1,18 \%$ & $1,28 \%$ \\
\hline Gravatal & $3,47 \%$ & $3,70 \%$ & $4,02 \%$ & $3,72 \%$ & $3,73 \%$ \\
\hline Imaruí & $9,30 \%$ & $9,33 \%$ & $10,62 \%$ & $12,97 \%$ & $10,61 \%$ \\
\hline Imbituba & $14,63 \%$ & $13,54 \%$ & $15,65 \%$ & $18,97 \%$ & $15,77 \%$ \\
\hline Jaguaruna & $6,47 \%$ & $6,34 \%$ & $6,39 \%$ & $5,97 \%$ & $6,29 \%$ \\
\hline Laguna & $25,33 \%$ & $24,74 \%$ & $21,48 \%$ & $18,49 \%$ & $22,39 \%$ \\
\hline Pedras Grandes & $1,38 \%$ & $1,44 \%$ & $1,46 \%$ & $1,20 \%$ & $1,37 \%$ \\
\hline Rio Fortuna & $0,78 \%$ & $0,71 \%$ & $0,68 \%$ & $0,63 \%$ & $0,70 \%$ \\
\hline Sangão & $3,18 \%$ & $3,17 \%$ & $3,40 \%$ & $3,60 \%$ & $3,35 \%$ \\
\hline Sta. Rosa de Lima & $0,61 \%$ & $0,51 \%$ & $0,45 \%$ & $0,32 \%$ & $0,47 \%$ \\
\hline São Ludgero & $2,04 \%$ & $1,99 \%$ & $1,99 \%$ & $1,76 \%$ & $1,94 \%$ \\
\hline São Martinho & $1,07 \%$ & $1,06 \%$ & $0,91 \%$ & $0,84 \%$ & $0,97 \%$ \\
\hline Treze de Maio & $2,91 \%$ & $2,70 \%$ & $1,67 \%$ & $1,38 \%$ & $2,13 \%$ \\
\hline Tubarão & $11,08 \%$ & $12,25 \%$ & $12,76 \%$ & $12,66 \%$ & $12,22 \%$ \\
\hline Total & $100,00 \%$ & $100,00 \%$ & $100,00 \%$ & $100,00 \%$ & $100,00 \%$ \\
\hline
\end{tabular}

Fonte: elaborada pelos autores. 
Os dados coligidos revelaram que quatro municípios têm participação percentual mais significativa no total de recursos do PBF repassados aos beneficiários da Amurel. Nesse sentido, Laguna foi a cidade que mais dinheiro recebeu desse programa, visto que o percentual a respeito chegou a $22,39 \%$ na média do quadriênio. Foi seguida por Imbituba $(15,77 \%)$, Tubarão $(12,22 \%)$ e Imaruí $(10,61 \%)$. Contudo, este último município aumentou sua participação a cada ano e superou Tubarão no ano final da série (12,97\% contra 12,66\%).

Por outro lado, o município de "Sta. R. de Lima" ficou com a última posição durante todos os quatro anos abrangidos, recebendo somente $0,47 \%$ do montante do PBF na microrregiāo da Amurel.

\subsection{Comparativo do Bolsa Família e as Principais Receitas Tributárias dos Municípios}

Uma abordagem possível para compreender a relevância econômica do Bolsa Família para os municípios pertencentes à Amurel consiste em confrontar os valores arrecadados pelas prefeituras em termos das receitas tributárias e os montantes repassados aos habitantes por intermédio desse benefício social federal.

Nesse rumo, na Tabela 3 constam os percentuais que os valores monetários do Bolsa Família representaram em comparação com a receita tributária dos municípios em tela entre 2010 e 2013, bem como a média quadrimestral respectiva.

Tabela 3 - Proporção do Bolsa Família sobre a receita tributária municipal (\%)

\begin{tabular}{l|r|r|r|r|r}
\hline Municípios & Ano 2010 & Ano 2011 & Ano 2012 & Ano 2013 & Média Quadr. \\
\hline Armazém & $40,88 \%$ & $43,84 \%$ & $32,21 \%$ & $30,53 \%$ & $36,03 \%$ \\
\hline Braço do Norte & $12,67 \%$ & $14,35 \%$ & $12,04 \%$ & $13,84 \%$ & $13,17 \%$ \\
\hline Capivari de Baixo & $13,07 \%$ & $12,70 \%$ & $13,28 \%$ & $11,00 \%$ & $12,45 \%$ \\
\hline Grão-Pará & $19,98 \%$ & $23,09 \%$ & $23,48 \%$ & $16,86 \%$ & $20,58 \%$ \\
\hline Gravatal & $22,19 \%$ & $36,53 \%$ & $25,99 \%$ & $23,48 \%$ & $26,16 \%$ \\
\hline Imaruí & $190,45 \%$ & $188,20 \%$ & $229,82 \%$ & $318,96 \%$ & $229,85 \%$ \\
\hline Imbituba & $7,22 \%$ & $7,88 \%$ & $12,08 \%$ & $13,54 \%$ & $9,87 \%$ \\
\hline Jaguaruna & $18,02 \%$ & $16,00 \%$ & $19,80 \%$ & $17,05 \%$ & $17,62 \%$ \\
\hline Laguna & $21,02 \%$ & $22,83 \%$ & $14,49 \%$ & $10,18 \%$ & $15,91 \%$ \\
\hline Pedras Grandes & $51,35 \%$ & $46,12 \%$ & $44,33 \%$ & $39,07 \%$ & $44,81 \%$ \\
\hline Rio Fortuna & $10,48 \%$ & $7,31 \%$ & $7,97 \%$ & $11,98 \%$ & $9,05 \%$ \\
\hline Sangáo & $40,96 \%$ & $37,41 \%$ & $43,87 \%$ & $33,93 \%$ & $38,49 \%$ \\
\hline Sta. Rosa de Lima & $25,32 \%$ & $19,39 \%$ & $15,78 \%$ & $10,37 \%$ & $16,96 \%$ \\
\hline Sáo Ludgero & $11,93 \%$ & $10,86 \%$ & $10,01 \%$ & $8,49 \%$ & $10,18 \%$ \\
\hline Sáo Martinho & $43,35 \%$ & $40,88 \%$ & $29,36 \%$ & $25,22 \%$ & $33,45 \%$ \\
\hline Treze de Maio & $43,69 \%$ & $29,45 \%$ & $21,45 \%$ & $23,48 \%$ & $29,00 \%$ \\
\hline Tubaráo & $4,40 \%$ & $4,42 \%$ & $4,57 \%$ & $4,32 \%$ & $4,43 \%$ \\
\hline Média Anual & $12,51 \%$ & $12,73 \%$ & $12,62 \%$ & $11,76 \%$ & $12,38 \%$ \\
\hline Fonte: Elabo & & $19 \%$ & & & \\
\hline
\end{tabular}

Fonte: Elaborada pelos autores, com dados obtidos no Portal da Transparência (CGU) e Finbra. 
Inicialmente cabe salientar que na Tabela 3 (e nas vindouras), por economia de espaço no texto foram omitidos os valores relativos ao Bolsa Família para os municípios, visto que esses dados podem ser encontrados em seção precedente.

No que concerne à expressão "Receita Tributária" municipal (código da conta 1100.00.00), esta diz respeito exclusivamente aos Recursos oriundos da competência de tributar como Impostos, Taxas e Contribuiçóes de Melhoria, conforme disposto na Constituição Federal do Brasil. No que tange ao cenário exposto, a média da região Amurel no quadriênio ficou em torno de 12,38\%. Com isso, para cada $\mathrm{R} \$ 100$ de receita tributária destas prefeituras, aproximadamente $\mathrm{R} \$ 12,38$ foi destinado pelo governo federal para esses municípios a título de Bolsa Família durante os quatro anos, em média.

Quanto à análise segregada por município, o resultado mais importante está vinculado ao de Imaruí, que apresentou a maior proporção dos recursos do benefício social perante as receitas municipais. Em 2010, o valor total do Bolsa Família destinado a este município equivaleu a $190,45 \%$ das receitas tributárias; no ano seguinte essa proporção caiu para 188,20\% e em 2012 alcançou 229,82\%. No ano de 2013 foi identificado o maior percentual $(318,96 \%)$, contribuindo para que a média quadrienal chegasse a $229,85 \%$ nessa cidade.

O segundo desempenho que mais se destacou refere-se à Pedras Grandes, cuja média dos quatro períodos mensurados atingiu 44,81\%. Nessa direção, em 2010 a proporção do montante do Bolsa Família na comparação com a receita tributária do município chegou a 51,35\%; em 2011 caiu para 46,12\%; em 2012 caiu novamente para 44,33\% e voltou a cair no ano que encerrou a série pesquisada (39,07\%). A terceira colocação nesse critério de avaliação coube à cidade de Sangão, cuja média quadrienal chegou a 38,49\% (40,96\% em 2010; 37,41\% em 2011; 43,87\% em 2012 e 33,93\% em 2013).

É interessante mencionar, ainda, que em apenas quatro municípios foram apurados desempenhos cujos percentuais ficaram aquém da média da microrregião (12,38\%): Tubarão (4,43\%), Rio Fortuna (9,05\%), Imbituba (9,87\%) e São Ludgero (10,18\%).

\subsection{Bolsa Família versus Receita com IPTU}

O tributo mais comumente associado ao Poder Público Municipal é o IPTU e no âmbito da microrregião Amurel a realidade sobre os montantes arrecadados com esse tributo está expresso na Tabela 4.

Tabela 4 - Proporção do Bolsa Família sobre a receita com IPTU (\%)

\begin{tabular}{l|r|r|r|r|r}
\hline Municípios & Ano 2010 & Ano 2011 & Ano 2012 & Ano 2013 & Média Quadr. \\
\hline Armazém & $211,8 \%$ & $167,2 \%$ & $150,0 \%$ & $118,1 \%$ & $161,8 \%$ \\
\hline Braço do Norte & $56,7 \%$ & $65,7 \%$ & $68,1 \%$ & $69,5 \%$ & $65,0 \%$ \\
\hline Capivari de Baixo & $156,5 \%$ & $164,7 \%$ & $355,0 \%$ & $152,1 \%$ & $207,1 \%$ \\
\hline Grão-Pará & $113,5 \%$ & $125,4 \%$ & $120,9 \%$ & $102,1 \%$ & $115,5 \%$ \\
\hline Gravatal & $162,9 \%$ & $148,1 \%$ & $177,9 \%$ & $156,8 \%$ & $161,4 \%$ \\
\hline Imaruí & $899,5 \%$ & $1.046,8 \%$ & $1.274,8 \%$ & $1.711,7 \%$ & $1.233,2 \%$ \\
\hline
\end{tabular}




\begin{tabular}{l|r|r|r|r|r}
\hline Municípios & Ano 2010 & Ano 2011 & Ano 2012 & Ano 2013 & Média Quadr. \\
\hline Imbituba & $77,7 \%$ & $62,8 \%$ & $70,2 \%$ & $77,4 \%$ & $72,0 \%$ \\
\hline Jaguaruna & $24,2 \%$ & $29,3 \%$ & $42,0 \%$ & $40,1 \%$ & $33,9 \%$ \\
\hline Laguna & $67,0 \%$ & $63,0 \%$ & $52,6 \%$ & $45,9 \%$ & $57,1 \%$ \\
\hline Pedras Grandes & $465,5 \%$ & $492,1 \%$ & $485,5 \%$ & $413,8 \%$ & $464,2 \%$ \\
\hline Rio Fortuna & $87,7 \%$ & $96,7 \%$ & $114,6 \%$ & $100,0 \%$ & $99,7 \%$ \\
\hline Sangáo & $223,4 \%$ & $236,1 \%$ & $241,5 \%$ & $154,6 \%$ & $213,9 \%$ \\
\hline Sta. Rosa de Lima & $1.603,0 \%$ & $289,2 \%$ & $386,7 \%$ & $270,7 \%$ & $637,4 \%$ \\
\hline São Ludgero & $53,5 \%$ & $56,1 \%$ & $56,7 \%$ & $48,9 \%$ & $53,8 \%$ \\
\hline São Martinho & $471,5 \%$ & $472,3 \%$ & $418,6 \%$ & $370,4 \%$ & $433,2 \%$ \\
\hline Treze de Maio & $173,2 \%$ & $168,4 \%$ & $101,0 \%$ & $79,6 \%$ & $130,6 \%$ \\
\hline Tubarão & $13,2 \%$ & $15,8 \%$ & $15,3 \%$ & $15,0 \%$ & $14,8 \%$ \\
\hline Média Anual & $50,6 \%$ & $52,8 \%$ & $53,0 \%$ & $51,4 \%$ & $52,0 \%$ \\
\hline
\end{tabular}

Fonte: elaborada pelos autores, com dados do Portal da Transparência (CGU) e Finbra.

$\mathrm{Na}$ Tabela 4 estão representados os percentuais relativos ao confronto entre o total destinado pelo programa federal aos municípios e a arrecadação anual total destes com o IPTU (conta 1112.02.00) durante os quatro anos investigados. Na média do quadriênio o valor total do Bolsa Família representou 52,0\% do montante arrecadado com IPTU no total da microrregião da Amurel.

Neste cenário novamente se destacou o município Imaruí, onde os recursos do benefício social superaram largamente a arrecadação de IPTU em todos os quatro anos da série em estudo. Ou seja, para cada $\mathrm{R} \$ 100$ arrecadados pela prefeitura em 2010, cerca de $\mathrm{R} \$ 899,50$ eram repassados pelo programa assistencial a este município. Nos anos seguintes essa proporção aumentou para 1.046,8\% em 2011, atingiu 1.274,8\% no ano de 2012 e finalizou o quadriênio com $1.711,7 \%$. Com isso, a média dessa cidade ficou em $1.233,2 \%$, superando fortemente os demais municípios abrangidos neste estudo.

Essa desproporção entre os dois valores considerados provavelmente tem sua origem no fato de que este município que possui grande parte do seu território como área rural. Como o tributo municipal "IPTU" não incide nas áreas não urbanas, a arrecadação a respeito tende a ser prejudicada.

Nesse sentido, o segundo município com maior relevância do Bolsa Família perante os tributos cobrados a título de IPTU foi Sta. Rosa de Lima, cuja média quadrienal chegou a 637,4\%. Na terceira posição figurou a cidade de "Pedras Grandes", com índice médio para os quatro anos de 464,2\%. A quarta colocação nesse ranking coube a "São Martinho", com média anual de 433,20\%, mas esse município superou Sta. Rosa de Lima nos anos de 2011 a 2013.

No diâmetro oposto, somente duas cidades tiveram média quadrimestral inferior ao percentual médio da microrregião: Tubarão, com 14,8\% e Jaguaruna com 33,9\%. 


\subsection{Bolsa Família versus Receita com IPVA (Cota-parte)}

Mesmo que a competência para arrecadar o IPVA seja da esfera estadual, em Santa Catarina 50\% desse tributo é repassado à prefeitura (daí a origem da designação "Cotaparte”) onde o veículo foi licenciado, conforme legislação específica. Quanto aos valores de IPVA (conta 1722.01.02) amealhados pelos municípios da Amurel no período de 2010 a 2013, o cenário registrado nas contas públicas está reproduzido em percentuais da Tabela 5.

Tabela 5 - Proporção do Bolsa Família sobre a receita com IPVA (cota-parte)

\begin{tabular}{l|r|r|r|r|r}
\hline Municípios & Ano 2010 & Ano 2011 & Ano 2012 & Ano 2013 & Média Quadr. \\
\hline Armazém & $39,71 \%$ & $43,12 \%$ & $42,54 \%$ & $36,29 \%$ & $40,41 \%$ \\
\hline Braço do Norte & $26,49 \%$ & $29,96 \%$ & $29,74 \%$ & $29,92 \%$ & $29,03 \%$ \\
\hline Capivari de Baixo & $60,37 \%$ & $56,78 \%$ & $52,49 \%$ & $49,29 \%$ & $54,73 \%$ \\
\hline Gráo-Pará & $28,09 \%$ & $31,13 \%$ & $28,27 \%$ & $27,19 \%$ & $28,67 \%$ \\
\hline Gravatal & $48,23 \%$ & $54,44 \%$ & $70,49 \%$ & $53,95 \%$ & $56,78 \%$ \\
\hline Imaruí & $265,84 \%$ & $268,44 \%$ & $283,57 \%$ & $327,17 \%$ & $286,26 \%$ \\
\hline Imbituba & $66,28 \%$ & $59,92 \%$ & $65,05 \%$ & $78,84 \%$ & $67,52 \%$ \\
\hline Jaguaruna & $61,90 \%$ & $61,48 \%$ & $58,21 \%$ & $54,55 \%$ & $59,03 \%$ \\
\hline Laguna & $11,25 \%$ & $106,80 \%$ & $86,12 \%$ & $72,65 \%$ & $94,21 \%$ \\
\hline Pedras Grandes & $48,64 \%$ & $49,33 \%$ & $48,20 \%$ & $43,09 \%$ & $47,32 \%$ \\
\hline Rio Fortuna & $17,90 \%$ & $16,32 \%$ & $15,01 \%$ & $14,50 \%$ & $15,93 \%$ \\
\hline Sangão & $38,73 \%$ & $39,60 \%$ & $38,70 \%$ & $42,81 \%$ & $39,96 \%$ \\
\hline Sta. Rosa de Lima & $46,91 \%$ & $40,70 \%$ & $32,89 \%$ & $23,36 \%$ & $35,96 \%$ \\
\hline Sáo Ludgero & $19,94 \%$ & $19,89 \%$ & $19,40 \%$ & $18,35 \%$ & $19,39 \%$ \\
\hline Sáo Martinho & $51,73 \%$ & $51,15 \%$ & $40,28 \%$ & $36,18 \%$ & $44,84 \%$ \\
\hline Treze de Maio & $53,36 \%$ & $53,05 \%$ & $31,19 \%$ & $25,68 \%$ & $40,82 \%$ \\
\hline Tubaráo & $11,08 \%$ & $12,61 \%$ & $12,38 \%$ & $12,38 \%$ & $12,11 \%$ \\
\hline Média Anual & $40,22 \%$ & $40,84 \%$ & $38,76 \%$ & $38,93 \%$ & $39,69 \%$ \\
\hline
\end{tabular}

Fonte: elaborada pelos autores, com dados do Portal da Transparência (CGU) e Finbra.

A partir do contexto expresso nesse demonstrativo é possível dessumir que a média da microrregiáo foi de 39,69\% no quadriênio no que se refere à proporção do Bolsa Família em relação ao valor arrecadado com a cota-parte do IPVA.

Além disso, cabe salientar alguns aspectos:

a) Os cinco municípios que apresentaram índices superiores a 50\% nesse parâmetro foram Imaruí (286,26\%), Laguna (94,21\%), Imbituba (67,52\%), Jaguaruna (59,03\%), Gravatal (56,78\%) e Capivari de Baixo (54,73\%). Entretanto, no último ano da série a cidade de Laguna já havia sido superada por Imbituba (72,65\% contra 78,84\%, respectivamente).

b) Novamente coube ao município de Imaruí a maior participação percentual, o que evidencia a relevância econômica do PBF para a economia dessa localidade. 
c) Os três municípios onde o valor do programa social apresentou menor proporção perante os recursos do IPVA foram, em ordem decrescente, Sáo Ludgero $(19,39 \%)$, Rio Fortuna (15,93\%) e Tubarão (com 12,11\%). Quanto às prováveis causas para essas proporções reduzidas, é razoável cogitar que, no caso de Rio Fortuna, como esta é uma das cidades com maior renda per capita do estado, há um contingente maior de veículos emplacados por habitante em comparação com outras cidades. Em relação a São Ludgero, é uma cidade com várias indústrias de grande porte que proporcionam a segunda maior arrecadação de ICMS da Amurel (só perdendo para Tubaráo), o que pode contribuir para um maior volume de automóveis registrados no município. Por sua vez, Tubarão é a cidade polo da região, possui o maior número de habitantes, a maior arrecadação de ICMS e há grande quantidade de indústrias sediadas na cidade, o que influencia no número de veículos e impacta no valor total do IPVA.

\subsection{Bolsa Família versus Receita com ICMS (Cota-parte)}

No plano de contas das administraçóes públicas brasileiras a conta relacionada ao ICMS (Cota-parte) refere-se ao valor da arrecadação de receita proveniente da transferência da participação de municípios na arrecadação do Imposto sobre a Circulação de Mercadorias e Prestação de Serviços - ICMS, no percentual de 25\% do total amealhado pelo estado. Deste percentual, $15 \%$ são divididos em partes iguais e $85 \%$ com base no movimento econômico do município, também chamado de valor adicionado (VA).

A partir dos dados levantados para a totalidade dos municípios da Amurel, a realidade encontrada acerca dos valores do PBF e os provenientes do ICMS (Cota-parte) entre 2010 e 2013 está exposta da Tabela 6 em termos de percentuais.

Tabela 6 - Proporção do Bolsa Família sobre a receita com ICMS (cota-parte)

\begin{tabular}{l|r|r|r|r|r}
\hline Municípios & Ano 2010 & Ano 2011 & Ano 2012 & Ano 2013 & Média Quadr. \\
\hline Armazém & $7,85 \%$ & $8,65 \%$ & $8,87 \%$ & $7,04 \%$ & $8,10 \%$ \\
\hline Braço do Norte & $7,15 \%$ & $8,07 \%$ & $8,41 \%$ & $7,67 \%$ & $7,83 \%$ \\
\hline Capivari de Baixo & $3,37 \%$ & $3,87 \%$ & $3,81 \%$ & $3,23 \%$ & $3,57 \%$ \\
\hline Grão-Pará & $3,35 \%$ & $3,55 \%$ & $3,48 \%$ & $3,30 \%$ & $3,42 \%$ \\
\hline Gravatal & $13,28 \%$ & $14,26 \%$ & $19,16 \%$ & $13,13 \%$ & $14,96 \%$ \\
\hline Imaruí & $39,50 \%$ & $39,45 \%$ & $45,25 \%$ & $57,27 \%$ & $45,37 \%$ \\
\hline Imbituba & $10,40 \%$ & $9,90 \%$ & $12,04 \%$ & $15,78 \%$ & $12,03 \%$ \\
\hline Jaguaruna & $13,47 \%$ & $13,51 \%$ & $13,82 \%$ & $12,76 \%$ & $13,39 \%$ \\
\hline Laguna & $40,37 \%$ & $37,18 \%$ & $29,70 \%$ & $26,97 \%$ & $33,56 \%$ \\
\hline Pedras Grandes & $5,38 \%$ & $5,36 \%$ & $5,40 \%$ & $4,24 \%$ & $5,09 \%$ \\
\hline Rio Fortuna & $2,65 \%$ & $2,47 \%$ & $2,42 \%$ & $2,32 \%$ & $2,46 \%$ \\
\hline Sangão & $7,22 \%$ & $7,22 \%$ & $7,46 \%$ & $7,31 \%$ & $7,30 \%$ \\
\hline Sta. Rosa de Lima & $2,97 \%$ & $2,53 \%$ & $2,34 \%$ & $1,68 \%$ & $2,38 \%$ \\
\hline Sáo Ludgero & $3,05 \%$ & $2,99 \%$ & $2,94 \%$ & $2,42 \%$ & $2,85 \%$ \\
\hline
\end{tabular}




\begin{tabular}{l|r|r|r|r|r}
\hline Municípios & Ano 2010 & Ano 2011 & Ano 2012 & Ano 2013 & Média Quadr. \\
\hline São Martinho & $4,68 \%$ & $4,74 \%$ & $4,21 \%$ & $3,88 \%$ & $4,38 \%$ \\
\hline Treze de Maio & $8,29 \%$ & $7,46 \%$ & $4,87 \%$ & $4,34 \%$ & $6,24 \%$ \\
\hline Tubarão & $3,56 \%$ & $4,24 \%$ & $4,44 \%$ & $4,11 \%$ & $4,09 \%$ \\
\hline Média Anual & $8,08 \%$ & $8,49 \%$ & $8,61 \%$ & $8,15 \%$ & $8,33 \%$ \\
\hline
\end{tabular}

Fonte: elaborada pelos autores, com dados do Portal da Transparência (CGU) e Finbra.

Durante o quadriênio visado o volume de recursos oriundos do Bolsa Família representou aproximadamente 8,33\%, em média, do que os municípios da Amurel receberam a título da cota-parte de ICMS (conta 1722.01.01).

Nessa linha de raciocínio, o ranqueamento dos municípios foi parcialmente alterado em relação aos outros dois tributos analisados nas seções anteriores. A cidade de Imaruí permaneceu como aquela cujos recursos do benefício social em evidência foram os mais representativos em termos de proporção ao arrecadado com o ICMS pelo município $(45,37 \%$ na média dos quatro anos). No ano de 2010 o índice apurado foi de $39,50 \%$ e caiu para 39,45\% no ano posterior. Em 2012 esse percentual subiu para 45,25\% e terminou o quadriênio analisado com $57,27 \%$.

O segundo posto, neste critério, ficou com Laguna visto que a pesquisa evidenciou os percentuais de 40,37\% (2010), 37,18\% (2011), 29,70\% (2012) e 26,97\% (2013), o que equivale à média de 33,56\% no transcorrer do período avaliado. Na terceira colocação figurou o município de Gravatal, cuja média quadrienal alcançou 14,96\%, tendo em vista os índices de 13,28\%, 14,26\%, 19,16\% e 13,13\% respectivamente para os anos de 2010 a 2013. A quarta posiçáo coube à cidade de Jaguaruna, com média de 13,39\% no quadriênio, enquanto que o quinto lugar foi ocupado pelo município de Imbituba (com 12,03\% na média dos quatro anos).

Todos os demais municípios ostentaram percentuais médios no quadriênio menores que a média da microrregião $(8,33 \%)$, com destaque para os municípios de Sta. Rosa de Lima (2,38\%), Rio Fortuna (2,46\%) e São Ludgero (2,85\%).

\subsection{Discussão dos Resultados}

Com fundamento nas informações oriundas das seções anteriores é relevante destacar os principais resultados deste estudo, conforme exposto a seguir.

O primeiro aspecto a salientar é a representatividade do Bolsa Família total do país sobre o PIB nacional, de vez que em 2010 situou-se em 0,370\% e nos anos seguintes passou para $0,395 \%$ (2011), 0,422\% (2012) e 0,468\% (2013). Esse mesmo raciocínio aplicado à microrregião da Amurel mostrou trajetória diferente, visto que cresceu e decresceu com o passar dos anos: foi $0,150 \%$ em 2010 , passou para $0,157 \%$ em 2011 , caiu para $0,151 \%$ em 2012 e encerrou a série com outra queda para $0,145 \%$ em 2013. No que concerne ao desempenho do estado, a proporção do PBF sobre o PIB estadual foi de $0,095 \%$ (em 2010), 0,099\% (em 2011), 0,108\% (em 2012) e 0,112\% (em 2013). Sendo assim, a média nacional destes anos se situou em 0,414\%, a estadual ficou em $0,104 \%$ e $0,151 \%$. 
Outra informação importante está vinculada ao percentual de participação dos integrantes da Amurel no valor total repassado pelo $\mathrm{PBF}$ aos municípios pesquisados. Acerca disso, na Tabela 2 verifica-se que, em média, cerca de 22,39\% desse montante foi destinado à cidade de Laguna, enquanto que às outras mais bem posicionadas tiveram índices médios no quadriênio de $15,77 \%$ para Imbituba, de $12,22 \%$ para Tubarão e de 10,61\% para Imaruí, enquanto que os demais municípios apresentaram participaçóes médias inferiores a $10 \%$.

Quanto à abordagem que compara a arrecadação tributária dos 18 municípios da microrregiáo da Amurel com o montante injetado por intermédio do PBF é pertinente destacar alguns aspectos.

O primeiro diz respeito à proporção assumida pelo valor total do Bolsa Família perante as receitas tributárias das prefeituras vinculadas a impostos, taxas e contribuiçóes de melhoria de competência exclusivamente municipal. Foi constatado que no quadriênio abrangido a média da região foi de $12,38 \%$, o que permite dessumir que, do total arrecadado pelos municípios a título de "Receita Tributária" (código 1100.00.000), os recursos do PBF assumiram proporção equivalente ao índice mencionado. Contudo, verificou-se que há municípios que superam largamente essa média, ressaltando a relevância desse benefício social para a economia local. É o caso dos municípios de Imaruí (com índice médio de 229,85\%), Pedras Grandes (44,81\%) e Sangão (38,49\%).

O segundo ponto reside na comparação entre os valores arrecadados pelos municípios da Amurel a título de IPTU (código 1112.02.00) no quadriênio. Os resultados dos cálculos, expressos na Tabela 4 denotaram que os valores do $\mathrm{PBF}$ equivaleram à média de $\mathrm{R} \$ 52$ de cada R \$ 100 cobrados de IPTU pelas prefeituras desta região nos quatro anos envolvidos no estudo. Entretanto, merecem destaque os percentuais apurados em quatro municípios. Em Imaruí os recursos do Bolsa Família totalizaram mais que doze vezes o valor total da arrecadação com IPTU (1.233,20\%); em Sta. Rosa de Lima essa proporção assumiu 637,40\%, enquanto que em Pedras Grandes ficou em 464,20\% e em São Martinho atingiu $433,20 \%$. Por outro lado, apenas os municípios de Jaguaruna e Tubarão tiveram índices menores que a média quadrienal desta microrregião $(52,0 \%)$ com médias de $33,90 \%$ e $14,80 \%$, respectivamente. Como possíveis explicaçóes para essa divergência entre os municípios podem ser aventadas hipóteses como densidade demográfica regional, extensão territorial, proporção de área rural, tipos de atividades econômicas e proximidade do litoral, entre outros fatores. Entretanto, nesta pesquisa esses cruzamentos de dados não foram efetuados.

O terceiro aspecto a salientar refere-se à arrecadação de IPVA (cota-parte). A pesquisa revelou que na microrregiáo da Amurel o valor deste tributo repassado pelo governo estadual aos municípios equivaleu a 39,69\% dos recursos alocados pelo PBF na média dos quatro anos estudados. Entretanto, em alguns municípios essa proporçáo foi bem mais acentuada, ou seja, no município Imaruí chegou a 286,26\% e em Laguna alcançou 94,21\%. No primeiro caso, o montante destinado pelo Bolsa Família aos beneficiários dessas cidades superou o valor do IPVA (cota-parte) alocado aos cofres das prefeituras nos anos de $2010(265,84 \%)$, 2011 com (268,44\%), 2012 com (283,57\%) e 2013 com a maior proporção de (327,17\%). Por outro lado, considerando as médias do quadriênio, os três principais municípios onde o 
valor do programa social apresentou menor proporção perante os recursos do IPVA foram em ordem decrescente São Ludgero com 19,39\%, Rio Fortuna com 15,93\% e Tubarão com $12,11 \%$.

$\mathrm{O}$ quarto item a evidenciar relaciona-se aos valores arrecadados pelas prefeituras em termos do repasse do ICMS (cota-parte). Nesse quesito, a comparação realizada evidenciou que o total da verba do benefício federal (PBF) encaminhado aos integrantes da microrregião em tela equivaleu a $\mathrm{R} \$ 8,33$ (em média) de cada $\mathrm{R} \$ 100$ repassados pelo governo de Santa Catarina aos municípios como cota-parte do ICMS. Contudo, no município de Imaruí esse indicador chegou à média de 45,37\% (com pico de 57,27\% em 2013) e no município de Laguna o percentual médio situou-se em 33,56\% (com 26,97\% no ano final da série), colocando-a na segunda posição da microrregião da Amurel. Destaca-se, também, que neste grupo de cidades o referido percentual subiu em todos os anos a partir de 2010 até 2012, mostrando crescimento superior dos recursos do Bolsa Família sobre o valor total repassado a título de cota-parte de ICMS ano a ano; mas houve um decréscimo no ano de 2013 nessa proporção.

Diferentemente do IPTU e do IPVA, cujo fato gerador está diretamente ligado aos limites territoriais dos municípios, o valor relativo à cota-parte do ICMS não estava circunscrito ao local de origem da mercadoria comercializada. Ou seja, mesmo que um produto fosse fabricado no município "Tubarão" (cerâmica para exportar, por exemplo), a arrecadação do ICMS poderia ocorrer em outro município onde o produto seria exportado (como o porto da cidade de Imbituba). Com isso, a cidade portuária era beneficiada com $100 \%$ do ICMS gerado a partir dessa comercialização. Referida realidade vigorou durante o período pesquisado (2010 a 2013), tendo sido modificada a partir de lei aprovada na Assembleia Legislativa de S. Catarina em 16/12/2014, que reduziu a $10 \%$ o repasse às cidades portuárias e destinou os outros $90 \%$ aos municípios produtores.

Outro aspecto a considerar é que cidades portuárias se beneficiam com o crédito de ICMS sobre produtos importados em transações interestaduais. Como esse percentual era diferente em cada estado brasileiro, a partir de 01/01/2012 as importaçóes feitas em todo o território nacional, levadas de um estado para outro, passaram a ser taxadas em $4 \%$, o que uniformizou a taxação respectiva no país. No que concerne ao foco deste estudo, esse tipo de tributação beneficiou o município de Imbituba que conta com a atividade portuária em seu território, em detrimento daqueles municípios sem portos e que não têm a possibilidade de contar com essa fonte de receita.

É válido salientar, também, que as divergências apuradas entre os municípios neste estudo nas receitas tributárias consideradas podem estar vinculadas à conclusão de Gouvêa et al. (2010) de que os tributos de competência municipal possuem maior potencial de arrecadação nos médios e grandes municípios, já que nos de pequeno porte que têm base econômica predominantemente rural a propriedade urbana é pouco significativa e, o setor de serviços também é pouco expressivo.

Por outro lado, convêm destacar que não foram cotejados os achados deste estudo com pesquisas assemelhadas em virtude de não terem sido encontradas pesquisas com esse foco em periódicos contábeis brasileiros, conforme citado na seção 3, anteriormente. 


\section{Conclusóes da Pesquisa}

A pesquisa priorizou responder questão ligada à importância do Programa Bolsa Família para a economia dos municípios da microrregião da Amurel. Adicionalmente, o estudo visava testar duas hipóteses: uma indagava acerca da possibilidade de que os recursos totais oriundos do PBF fossem distribuídos de forma heterogênea e, por isso, tivessem níveis distintos de relevância para a economia das cidades desta microrregiâo e outra que questionava se os valores desses benefícios superavam as fontes tradicionais de receitas tributárias dos municípios, como o IPTU e as cotas-partes de IPVA e ICMS no contexto da Amurel.

Pelo exposto nas seçóes precedentes, entende-se que a questão estudo foi convenientemente respondida, bem como foi confirmada totalmente a hipótese quanto aos níveis distintos de importância do programa assistencial entre os dezoito municípios pertencentes à regiâo Amurel. Porém, a outra hipótese mostrou-se parcialmente comprovável, sendo que dez municípios desta regiáo o percentual do montante do PBF superou o total arrecadado com IPTU nos quatros anos avaliados (com máxima de 1.233,20\% e mínima de $115,50 \%$ entre os dez que superaram a proporção do Bolsa Família sobre este tributo); enquanto que o valor arrecadado com IPVA no município "Imaruí" também foi superado pelo total do PBF nos anos de 2010 a 2013, propiciando média quadrienal de 286,26\%. Além disso, os resultados do estudo evidenciaram que o PBF teve um percentual de participação médio perante o PIB da Amurel (de 0,151\%) inferior à participação deste no PIB brasileiro (de 0,414\%), mas superior à participação do mesmo frente ao PIB de Santa Catarina (de $0,104 \%$ ), tendo como base o quadriênio abrangido. Destarte, como o objetivo do estudo consistia em mensurar a proporção desse programa federal perante as principais receitas tributárias municipais e dos valores de PIB respectivos, os autores consideraram-no atingido, conforme explicitado nas tabelas já comentadas.

No que tange à contribuição do estudo, os autores consideram que esta reside especialmente no fato de evidenciar o aspecto da relevância econômica dos recursos alocados pelo Bolsa Família na área geográfica citada, especialmente por estes superarem (em alguns casos) ou terem um percentual bastante expressivo em relaçáo às principais formas de arrecadação tributária municipal. Com isso, foi possível contribuir para revelar um aspecto contábil/tributário que ainda não foi devidamente explorado pela literatura da área contábil brasileira.

Quanto às limitaçóes do estudo é cabível destacar alguns aspectos. Os dados primários sobre os municípios da Amurel (arrecadação, PIB, Bolsa Família etc.) utilizados neste texto foram coligidos de fontes como Finbra, IBGE, Portal da Transparência (CGU). Portanto, assumiu-se que os mesmos sejam verídicos e confiáveis em termos de representarem o cenário real das cidades da Amurel nos quatro anos enfocados. Além disso, optou-se por inflacionar os valores monetários dos anos de 2010, 2011 e 2012 para o poder aquisitivo equivalente ao ano de 2013 pelo IPCA. Se utilizado outro índice inflacionário provavelmente os montantes $(\mathrm{R} \$$ ) computados nos cálculos que fundamentaram as tabelas do texto teriam valores monetários um pouco diferentes e esse detalhe deve ser levado em consideração quando desta leitura, mesmo que as proporçóes (percentuais) provavelmente não se alterem de forma significativa. 
No que tange às recomendaçôes para trabalhos futuros, talvez seja interessante utilizar a abordagem adotada nesta pesquisa nos demais municípios/regióes catarinense e/ ou brasileiros para corroborar, comparar ou contestar acerca da relevância da proporçáo do PBF nos municípios, regióes ou estados da federação. Ainda, caberiam estudos assemelhados em outros grupos de cidades, como as 10 maiores do estado barriga-verde em número de habitantes, ou comparativos entre o grupo de municípios mais desenvolvidos economicamente e as cidades com menores índices de desenvolvimento, entre outras possibilidades.

\section{Referências}

Alvez, J. E. D. \& Cavenaghi, S. (2013). In: Campello, T. \& Neri, M. C. (org.). Programa Bolsa Família: uma década de inclusão e cidadania. Brasília: Ipea, pp. 233-246.

ASSOCIAÇÃO DOS MUNICÍPIOS DA REGIÃO DE LAGUNA. AMUREL. (2015). Mapas. Disponível em:<http://www.amurel.org.br/cms/pagina/ver/ codMapaItem/45287>. Acesso em: 13 de setembro de 2017.

Andrade, N. de A. (2010). Contabilidade pública na gestão municipal: métodos com base na LC n. 101/00 e nas classificaçóes contábeis advindas da SOF e STN. São Paulo: Atlas.

Andrade, N. de A. (2002). Contabilidade pública na gestão municipal. São Paulo: Atlas.

Atlas do Desenvolvimento Humano. (2015). O IDHM. Disponível em: <http://www. atlasbrasil.org.br/2013/pt/o_atlas/idhm/>. Acesso em: 09/11/2016.

Avila, R. I. \& Conceição, J. B. S. (2015). O capital no século XXI e sua aplicabilidade à realidade brasileira. Cadernos IHU Ideias. São Leopoldo: Universidade do Vale do Rio dos Sinos, 13 (234).

Babbie, E. (1999). Métodos de pesquisa survey. Belo Horizonte: Editora UFMG.

Barbosa, A. L. N. de H. \& Corseuil, C. H. L. (2013). In: Campello, T. \& Neri, M. C. (org.). Programa Bolsa Família: uma década de inclusão e cidadania. Brasília: Ipea, pp. 327-340.

Campello, T. (2015). Ministra Tereza Campello explica como Brasil se tornou exemplo de inclusão. Blog Luiz Muller. Post de 04/06/2015. Disponível em: <https://luizmullerpt. wordpress.com/2015/06/04/ministra-tereza-campello-explica-como-brasil-se-tornouexemplo-de-inclusao/>. Acesso em: 21 dez. 2016.

Cireno, F., Silva, J. \& Proença, R. P. (2013). In: Campello, T. \& Neri, M. C. (org.).

Programa Bolsa Família: uma década de inclusão e cidadania. Brasília: Ipea, pp. 297-304. 
Collins, J. \& Hussey, R. (2005). Pesquisa em administração: um guia prático para alunos de graduação e pós-graduação. 2. ed. Porto Alegre: Bookman.

Craveiro, C. B. A. \& Ximenes, D. de A. (2013). In: Campello, T. \& Neri, M. C. (org.). Programa Bolsa Família: uma década de inclusão e cidadania. Brasília: Ipea, pp. 109-124.

Gouvêa, M. A., Varela, P. S. \& Farina, M. C. (2010). Avaliação das relaçôes entre receita tributária e desenvolvimento econômico e social dos grupos 3, 4 e 5 de municípios paulistas, segundo o IPRS: uso da análise multivariada de variância. Revista Eletrônica de Administração, 16 (2), pp. 1-21.

Jannuzzi, P. de M. \& Pinto, A. R. (2013). In: Campello, T. \& Neri, M. C. (org.).

Programa Bolsa Família: uma década de inclusão e cidadania. Brasília: Ipea, pp. 179-192.

Kohama, H. (2012). Contabilidade pública: teoria e prática. 12. ed. São Paulo: Atlas.

Matias, A. B. \& Campello, C. A. G. B. (2000). Administração financeira municipal. São Paulo: Atlas.

Ministério do Desenvolvimento Social e Combate à Fome [MDS]. (2016). O que é: conheça o Programa Bolsa Família. Disponível em: http://mds.gov.br/assuntos/bolsafamilia/o-que-e. Acesso em: 05/12/2016.

Oliveira, L. F. B. de \& Soares, S. S. D. (2013). In: Campello, T. \& Neri, M. C. (org.). Programa Bolsa Família: uma década de inclusão e cidadania. Brasília: Ipea, pp. 285-296.

Oliveira, L. F. B. de \& Soares, S. S. D. (b). (2013). In: Campello, T. \& Neri, M. C. (org.). Programa Bolsa Família: uma década de inclusão e cidadania. Brasília: Ipea, pp. 341-358.

Rasella, D., Aquino, R., Santos, C. A. T., Paes-Sousa, A. R. \& Barreto, M. L. (2013). In: Campello, T. \& Neri, M. C. (org.). Programa Bolsa Família: uma década de inclusão e cidadania. Brasília: Ipea, pp. 247-262.

Reis, P. R. da C., Costa, T. de M. T. da \& Silveira, S. F. R. (2013). Receita pública e bemestar social nos municípios mineiros emancipados no período de 1988 a 1997. Revista Eletrônica de Administração, 19 (1), pp. 61-82.

Richardson, R. J. (1999). Pesquisa social: métodos e técnicas. $3^{a}$ ed. São Paulo: Atlas.

Santos, L. M. P., Guanais, F., Porto, D. L., Morais Neto, O. L., Stevens, A., CortezEscalante, J. J. \& Modeste, L. (2013). In: Campello, T. \& Neri, M. C. (org.). Programa Bolsa Família: uma década de inclusão e cidadania. Brasília: Ipea, pp. 263-272.

Silveira, F. G., Campolina, B. \& Horn R. van (2013). In: Campello, T. \& Neri, M. C. (org.). Programa Bolsa Família: uma década de inclusão e cidadania. Brasília: Ipea, pp. 305-326. 
Silveira Neto, R. da M. \& Azzoni, C. R. (2013). In: Campello, T. \& Neri, M. C. (org.). Programa Bolsa Família: uma década de inclusão e cidadania. Brasília: Ipea, pp. 217-232.

Soares, F. V., Ribas, R. P. \& Osorio, R. F. (2010). Evaluating the impact of Brazil's Bolsa Família: cash transfer programs in comparative perspective. Latin American Research Review, 45 (2), pp.173-190.

Souza, P. H. G. F. de \& Osorio R. G. (2013). In: Campello, T. \& Neri, M. C. (org.). Programa Bolsa Família: uma década de inclusão e cidadania. Brasília: Ipea, pp. 139-156.

Tepperman, J. (2016). Brazil's antipoverty breakthrough: the surprising success of Bolsa Família. Foreign Affairs, jan./fev. 2016. Disponível em: https://www.foreignaffairs.com/ articles/brazil/2015-12-14/brazils-antipoverty-breakthrough. Acesso em: 18/12/2016. 